Acta vet. scand. $1978,19,549-560$.

From the National Veterinary Institute, Oslo, and the Department of Anatomy, Veterinary College of Norway.

\title{
ULTRASTRUCTURE OF COLONIC EPITHELIAL CELLS IN VITAMIN E AND SELENIUM DEFICIENT PIGS
}

\author{
By
}

Jon Teige jr. and Per H. J. Nafstad

TEIGE, JON jr. and PER H. J. NAFSTAD: Ultrastructure of colonic epithelial cells in vitamin $E$ and selenium deficient pigs. Acta vet. scand. 1978, 19, 549-560. - Pigs deficient in vitamin E and selenium had a decreased contrast of the intracellular membranes compared with pigs supplemented with vitamin E and selenium. Other common changes in the deficient animals included a reduced number of microvilli, with a short and irregular appearance, numerous swollen mitochondria with empty spaces and intercellular oedema. It is suggested that these morphological changes are attributed to the insufficient supply of vitamin $\mathrm{E}$ and selenium, though it is not excluded that particular intestinal factors may participate in the development of the lesions.

cellular membranes; vitamin E and selenium deficiency; colonic epithelial cells; pig.

In pigs the aetiological role of vitamin $\mathbf{E}$ and selenium deficiency has been well established in diseases like hepatosis dietetica, skeletal muscle degeneration and "mulberry heart" (Grant 1961, Nafstad \& Tollersrud 1970, Jenkins \& Hidiroglou 1972). On the cellular level it has been suggested that both vitamin $\mathbf{E}$ and selenium are important for cellular membranes (Lucy 1972, Brown \& Pollock 1972, Diplock 1974, Combs et al. 1975). Electron-microscopic examination of livers has thus shown that a lowered membrane contrast occurs in vitamin $\mathrm{E}$ deficient ducklings (Vos 1972). A similar effect of vitamin $\mathrm{E}$ deficiency on the membrane contrast of intestinal cells has also been recorded in man and ducklings (Molenaar et al. 1968, 1970).

In this laboratory we have performed 3 experiments to study the influence of diet, especially the effect of vitamin $\mathbf{E}$ and sele- 
nium, on swine dysentery (Teige et al. 1977, 1978). Prior to inoculation, material was collected and examined in order to obtain information regarding the influence of both vitamin $\mathrm{E}$ and selenium on the ultrastructure of colonic epithelial cells in pigs. The findings are presented below.

\section{MATERIALS AND METHODS}

Biopsies for electron-microscopical examination were derived from pigs Nos. 6, 8, 13, 15, 33, 34, 35 and 40 in Exps. I and II (Teige et al. 1977, 1978) 3 to 4 days before the inoculation. In accordance with the diets given the animals are designated as either deficient (Nos. 6, 8, 33 and 34) or supplemented pigs (Nos. 13, 15, 35 and 40). Further information on animals, diets, laboratory analyses and results as well as liver selenium values are given in the mentioned reports. The individual plasma- $\alpha$-tocopherol values of pigs Nos. 33, 34, 35 and 40 in Exp. II were 0.65, $0.65,2.55$ and $1.50 \mu \mathrm{g}$ per $\mathrm{ml}$, respectively. No signs of enteric disorders had been observed in any of the pigs during the feeding period. Before the removal of the biopsies the pigs were anaesthetized and a section was made in the left side of the abdomen. A piece of the wall in the spiral colon, measuring approx. $0.5 \mathrm{~cm} \times 2 \mathrm{~cm}$, was taken out and immediately fixed in $3 \%$ glutaraldehyde dissolved in Millonig's phosphate buffer and $3 \%$ Macrodex. The wounds in the colonic and abdominal walls were afterwards stitched together. The biopsies were post-fixed in $2 \%$ buffered osmic acid overnight. After dehydration in acetone the material was embedded in Araldite. The sections, mainly $1 \mu$ thick, were cut with a Reichert Om U 2 ultramicrotome and stained with Toluidine blue. Usually sites in the middle of the crypts of Lieberkühn were selected with a light microscope and processed for electron microscopy. The ultrathin sections were stained with either uranyl acetate and lead citrate or lead citrate alone and examined in a Siemens Elmiscop I A. Dark, shrunken epithelial cells were avoided during the examination; only those cells regarded as vital at the time of fixation were considered.

\section{RESULTS}

\section{Supplemented animals}

The microvilli were usually numerous with a uniform and slender appearance (Fig. 1). They were regularly spaced and 


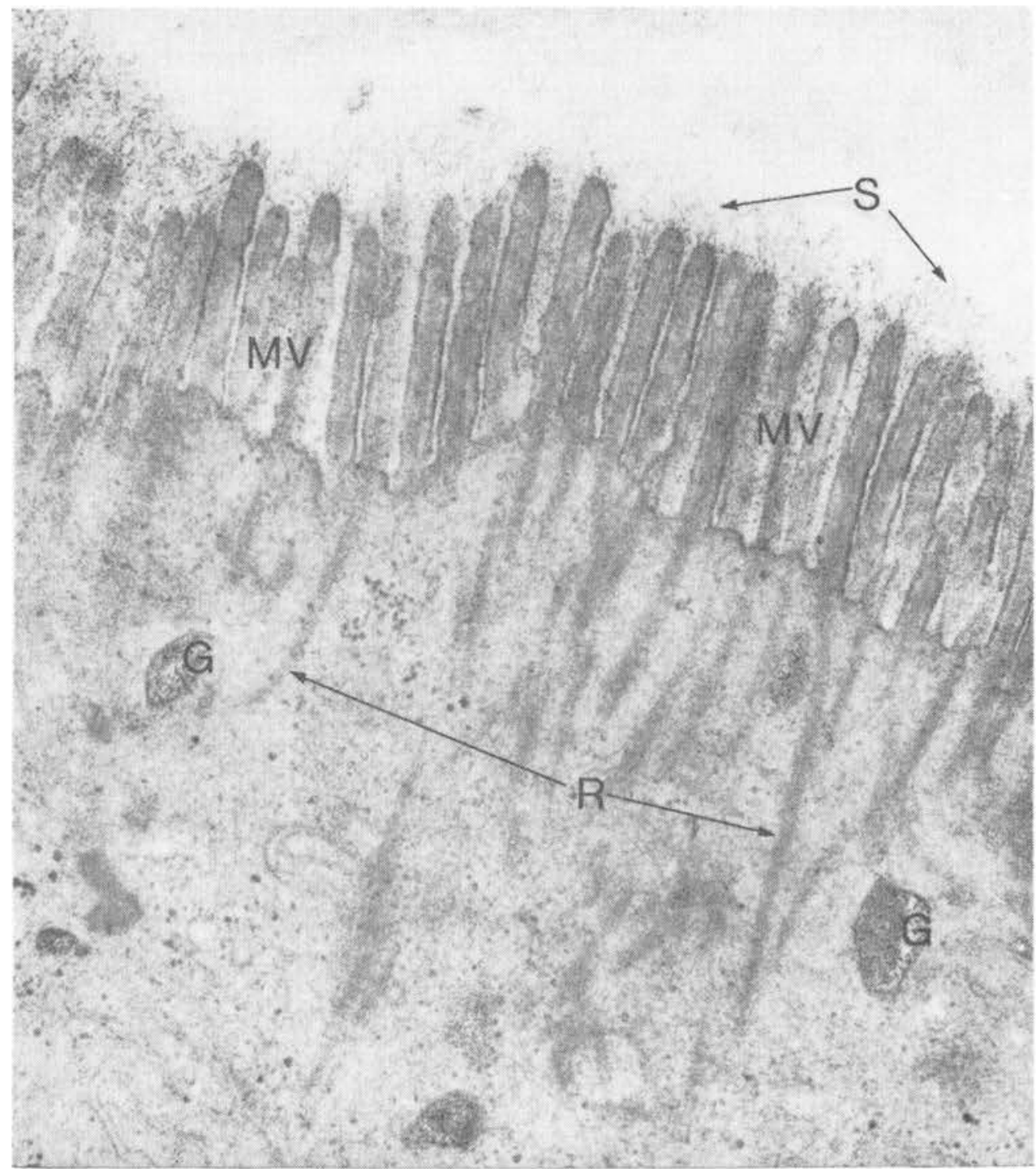

F i g u r e 1. Juminal apex of a colonic epithelial cell from an animal on supplemented nutrition. In the micrograph a normal morphology of the microvilli as well as distribution of the microvilli are shown. G: colonic immunoglobulin granules; MV: microvilli; R: microvillial rootlets; S: surface coat. $\times 44,000$.

contained straight bundles of filaments which ran from the tip and extended more than $1 \mu$ into the cytoplasma as rootlets. Distinct membranes covered the surface of the microvilli (Fig. 
2). A surface coat covered their apex towards the lumen. The mitochondrial membranes were usually distinct, and membranes of the rough endoplasmatic reticulum were also usually distinct in this material (Fig. 3). The intracellular membranes of the pigs in Exp. II were, however, sometimes difficult to see. Numerous membrane-bound granules, up to $0.5 \mu$ in diameter, were present in the terminal web region of the cells. These oval-shaped granules varied in electron density, but usually contained a fine granular material (Figs. 1-2).

The lateral surface of the cells showed commonly slender interdigitations, and the intercellular spaces were regular, approx. $200 \AA$ (Fig. 3). A slight increase in the intercellular space occurred occasionally between the epithelial cells.

\section{Deficient animals}

The microvilli were usually short with an irregular and sometimes swollen appearance. A reduction in their number was frequently observed (Figs. $4-5$ ). The thickness of the surface coat was reduced and often difficult to see. The extensions of the microvillial rootlets into the cytoplasm were markedly reduced, sometimes not visible at all (Figs. $4-5$ ). The membranes covering the surface of the microvilli were visible but sometimes with only vague outlines. Numerous swollen mitochondria were seen and they often contained apparently empty irregular spaces of different size (Fig. 6). Mitochondria with reduced swelling but with rather indistinct mitochondrial membranes were also observed (Fig. 6 inset).

The membranes of the rough endoplasmatic reticulum were difficult to detect, although the chained location of ribosomes indicated in many areas the existence of these membranes.

F i g u r e 2. A nearly horizontal section of the apical part of colonic epithelial cells from an animal on supplemented nutrition. The normal distribution of microvilli is easily recognized.

G: colonic immunoglobulin granules; MV: cross-sectioned microvilli;

R: cross-sectioned microvillial rootlets. $\times 33,000$.

Figure 3. The mitochondria in the colonic epithelial cells of supplemented animals show distinct membranes and a normal matrix density. The lateral surface of the cells show slender interdigitations, $\mathrm{I}$, and some desmosomes, D.

M: mitochondria; P: plasma membrane. $\times 60,000$. 


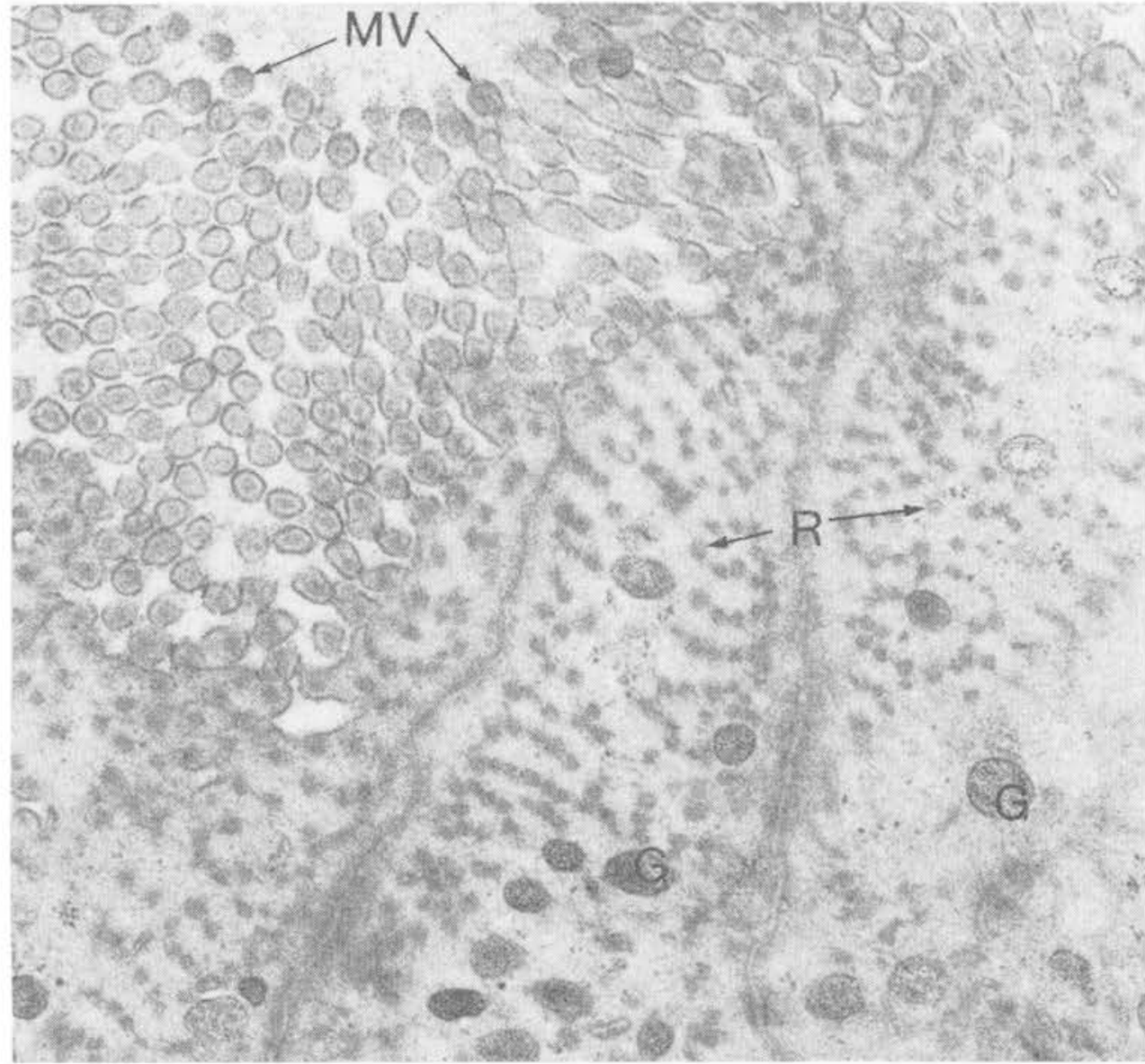

Fig. 2

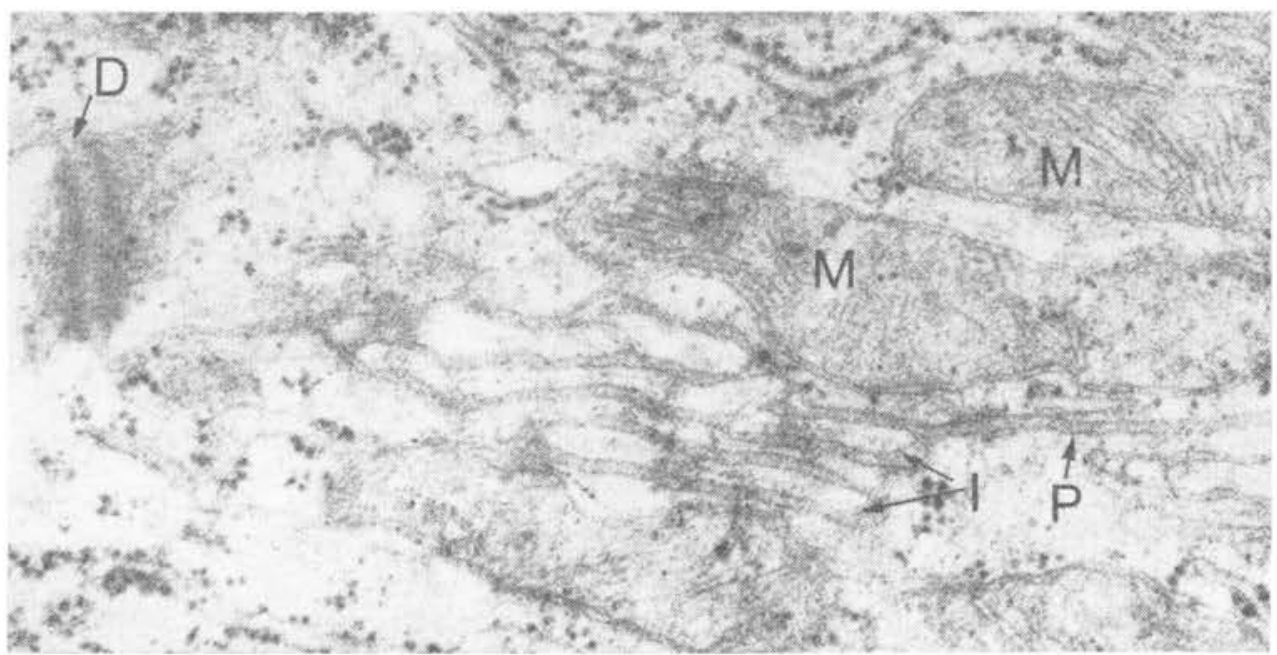

Fig. 3 


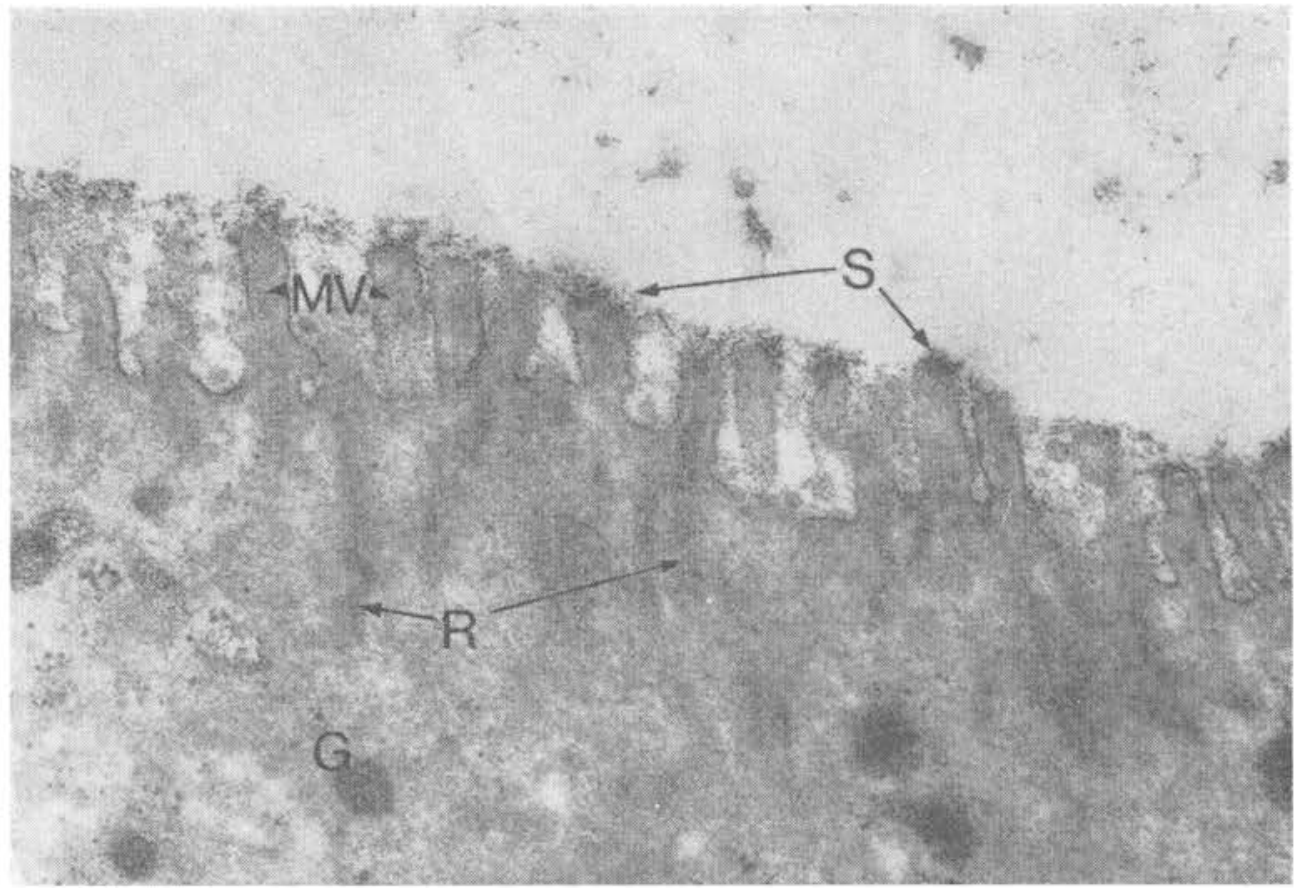

Fig. 4

Fig. 5

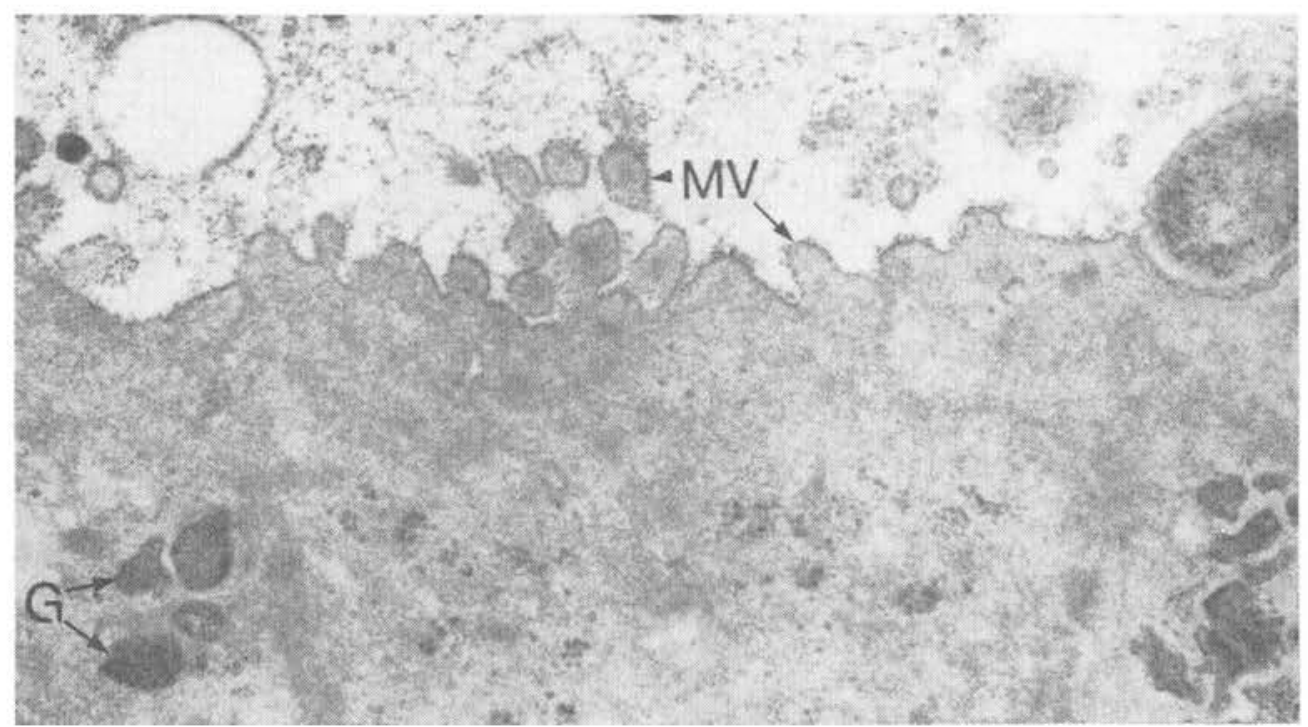

Figure 4. Colonic epithelial cell from an animal on deficient nutrition. Note the short irregular microvilli as well as the "subdeveloped" rootlets and surface coat.

G: colonic immunoglobulin granules; MV: microvilli; R: rootlets;

S: surface coat. $\times 44,000$.

Figure 5. Nearly horizontal section of the apical part of a colonic cell in a deficient animal. The microvillial distribution should be compared with that of the supplemented animal shown in Fig. 2.

G: colonic immunoglobulin granules; MV: microvilli. $\times 44,000$. 


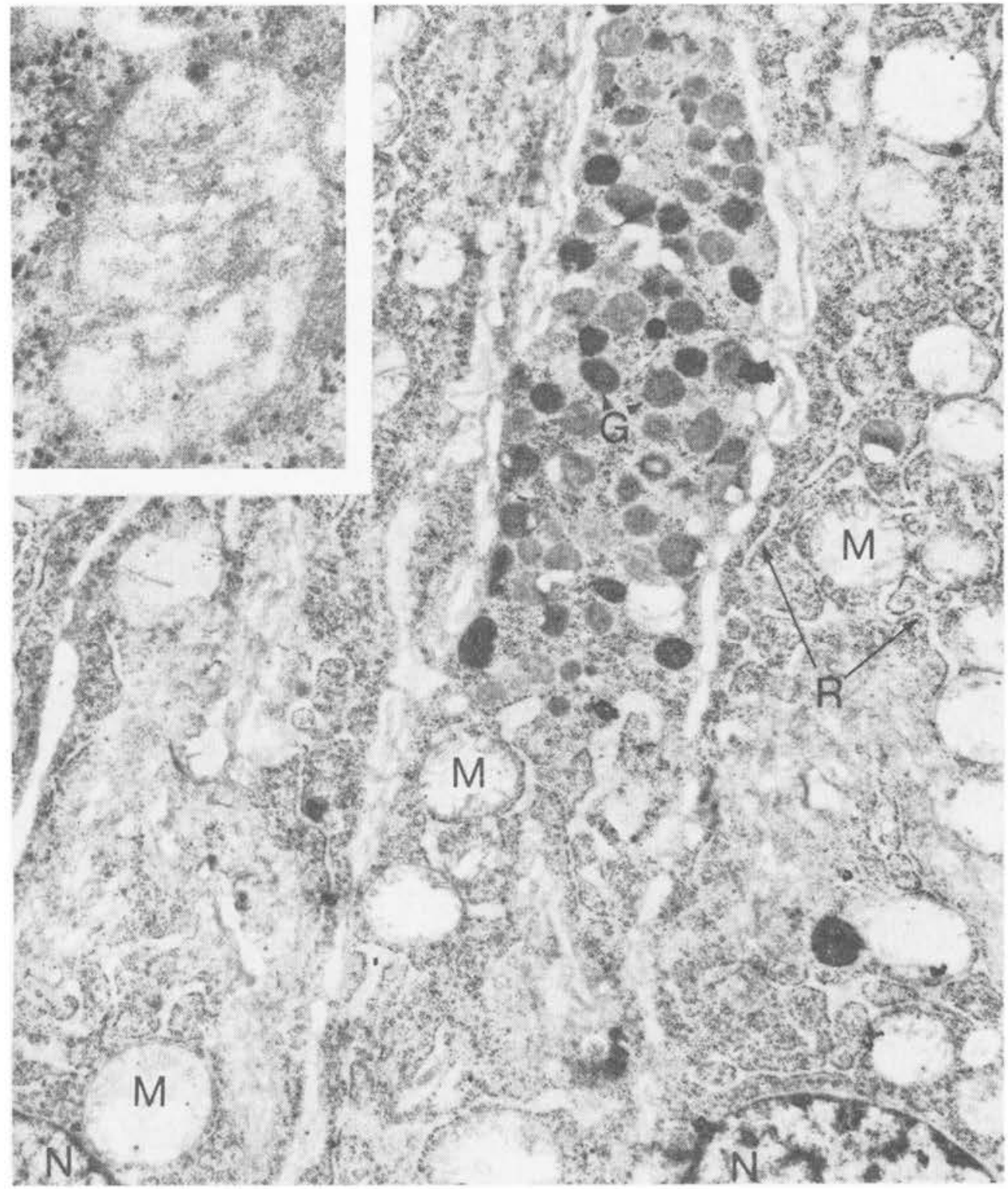

Figure 6. Colonic epithelial cells from an animal on deficient nutrition. A general impression in this material is the increased fragility of the mitochondria possibly due to reduced integrity of the mitochondrial membranes. Even when the mitochondrial morphology was moderately disturbed, the mitochondrial membranes were hardly detectable (inset).

G: mucous granules; $\mathrm{M}$ : mitochondria; $\mathrm{N}$ : epithelial cell nuclei; $\mathrm{R}$ : rough endoplasmatic reticulum. $\times 37,500$, inset $\times 60,000$. 
Numerous free ribosomes also appeared in the epithelial cells, especially towards the nuclear region (Fig. 6). Larger intercellular spaces were observed (Fig. 6). These changes seemed to be most pronounced towards the cell basis. Despite the intercellular changes intact desmosomal attachments were found. The granules in the terminal web region were relatively small and with more irregular outlines than the granules of the supplemented animals. No intercellular oedema was observed towards the luminal surface. The nuclear membranes were usually difficult to see. Single perinuclear rows of ribosomes, however, indicated the position of the outer nuclear membranes. Otherwise there were no conspicuous nuclear changes (Fig. 6).

\section{DISCUSSION}

This study revealed morphologic differences between the colonic epithelium in pigs both supplemented with and deficient in vitamin $\mathrm{E}$ and selenium. Deficiency seemed primarily to have induced a decreased contrast of cellular membranes. Swollen translucent mitochondria with intercellular oedema and a reduced number of microvilli with a short and irregular appearance were also conspicuous in the deficient pigs.

Vitamin $\mathrm{E}$ seems to be the only nutritional factor hitherto studied in connection with membrane contrast in intestinal epithelial cells. Molenaar et al. (1968) found that no membranes could be seen in jejunal epithelial cells in 2 vitamin $\mathrm{E}$ deficient human patients. After supplementation with this vitamin the membranes became more visible. In another study Molenaar et al. (1970) observed a loss of positive membrane contrast especially in the outer membrane of the mitochondria in jejunal epithelial cells from vitamin $\mathrm{E}$ deficient ducklings compared with animals supplemented with this vitamin. The plasma membrane showed more contrast, but to a lesser degree than in the control animals. The observations on membrane contrast in those reports and in the present study revealed that the supplementation used in all investigations had almost identical effects, though in this connection a comparison is drawn between pigs, ducklings and man. Molenaar et al. do not, however, show the selenium balance in neither the human beings nor the ducklings. Vos (1972) further assumed that the selenium content of the diet most probably did not influence his results showing a decreased membrane contrast in liver cells of vitamin $\mathrm{E}$ deficient 
ducklings compared with controls. Although vitamin E and selenium may have different abilities regarding the ultrastructure of the cell, both factors are supposed to act as membrane stabilizers (Brown \& Pollock 1972, Combs et al. 1975). The oedema formation observed in disorders like mulberry heart disease and nutritional muscle degeneration of pig and exudative diathesis of chickens indicates that the membrane permeability may also be disturbed in conditions associated with vitamin $\mathrm{E}$ and selenium deficiency. Lack of these nutritional factors is also associated with ultrastructural alterations indicative of increased membrane permeability (Porta et al. 1968). The intercellular oedema and the mitochondrial swelling demonstrated in the deficient pigs may therefore have been caused by such a defect. Short and irregular microvilli are further emphasized as 1 feature in the deficient pigs of the present study. Porta et al. observed, however, a diminution in number of normally numerous slender microvilli of the sinusoidal border of hepatocytes in rats given a vitamin $\mathrm{E}$ and selenium deficient diet. In this experiment, however, some shortening of microvilli was also seen in the groups given the diet supplemented with vitamin $\mathrm{E}$ or selenium.

Among the alterations noted in the colonic epithelium of pigs with swine dysentery are short, irregular and sparse microvilli, intercellular oedema and swollen mitochondria (Taylor \& Blakemore 1971, Glock 1971). Similar degenerative lesions or some of them have also been seen in jejunal epithelium from pigs with enteritic diseases unrelated to swine dysentery (Kenworthy et al. 1967, Drees \& Wuxler 1970, Mouwen 1972). Intercellular oedema is also occasionally described in reports concerning the ultrastructure of intestinal epithelium from "normal" animals (Hayward \& Johnston 1961, Sibalin \& Bjørkman 1966, Thake 1968). Drees \& Waxler found, however, that the oedema was more pronounced in pigs with than without diarrhoea. It seems that animals with enteritic disorders and the deficiency pigs of the present study which did not show any signs of intestinal disorders display some common ultrastructure features. It cannot therefore be excluded that the colonic epithelium from the deficient pigs has decreased resistance to further degenerative influences and also to infectious agents. After removal of biopsies pigs in the present study were inoculated with material from swine dysentery (Teige et al. 1977, 1978). Resistance to the dis- 
ease was found to be far better in the supplemented than in the deficient pigs. The degenerative changes, including altered microvilli and membranes, demonstrated in the colonic epithelium of deficient animals may to a certain degree have influenced this result. Such changes can be supposed to decrease the resistance to spirochaetes and other intestinal factors occurring in swine dysentery. In this connection it should be noted that detachment of degenerating epithelial cells are described as one of the initial steps in the development of the lesions in swine dysentery (Callinan \& Russell 1975).

The granules observed in the apical part of the epithelial cells in the supplemented as well as the deficient animals seemed to correspond to the secretory immunoglobulin granules in the large intestine in sheep described by Schofield \& Atkins (1970). Those authors suggest that the granules play a central role in the elaboration of the immunoglobulin-containing surface coat of the epithelial cells. In this study the reduced morphological integrity of the granules may be regarded in connection with the reduced surface coat of the cells and thus be responsible for a reduced intestinal defence mechanism.

Generally, a better membrane contrast was observed in the pigs of Exp. I than in Exp. II. This observation which was somewhat unexpected when seen in relation to their vitamin $\mathrm{E}$ and selenium balance (Teige et al. 1977, 1978) will be discussed in a subsequent paper.

\section{REFERENCES}

Brown, J. H. \& S. H. Pollock: Stabilization of hepatic lysosomes of rats by vitamin $\mathrm{E}$ and selenium in vivo as indicated by thermal labilization of isolated lysosomes. J. Nutr. 1972, 102, 1413-1419.

Callinan, R. B. \& E. G. Russell: Aetiology and pathogenesis of swine dysentery - recent advances. Aust. vet. J. 1975, 51, 423-427.

Combs, G. F. jr., T. Noguchi \& M. L. Scott: Mechanisms of action of selenium and vitamin $\mathrm{E}$ in protection of biological membranes. Fed. Proc. 1975, 34, 2090-2095.

Diplock, A. T.: The nutritional and metabolic roles of selenium and vitamin E. Proc. Nutr. Soc. 1974, 33, 315-322.

Drees, D. T. \& G. L. Waxler: Enteric colibacillosis in gnotobiotic swine: An electron microscopic study. Amer. J. vet. Res. 1970, $31,1159-1171$.

Glock, R. D.: Studies on the etiology, hematology and pathology of swine dysentery. Thesis, Iowa State Univ. 1971, 169 pp. 
Grant, C. A.: Morphological and aetiological studies of dietetic microangiopathy in pigs ("Mulberry heart"). Acta vet. scand. 1961, 2, Suppl. 3.

Hayward, A. F. \& H. S. Johnston: The fine structure of the epithelium of the colon in the mouse. Scot. med. J. 1961, 6, 416-425.

Jenkins, K. J. \& M. Hidiroglou: A review of selenium/vitamin E responsive problems in livestock: A case for selenium as a feed additive in Canada. Canad. J. Anim. Sci. 1972, 52, 591-620.

Kenworthy, R., J. M. Stubbs \& G. Syme: Ultrastructure of smallintestinal epithelium in weaned and unweaned pigs and pigs with post-weaning diarrhoea. J. Path. Bact. 1967, 93, 493-498.

Lucy, J. A.: Functional and structural aspects of biological membranes: A suggested structural role for vitamin $\mathrm{E}$ in the control of membrane permeability and stability. Proc. int. conf. vitamin $\mathrm{E}$ and its role in cellular metabolism. Ann. N. Y. Acad. Sci. 1972, 203, 4-11.

Molenaar, I., F. A. Hommes, W. G. Braams \& H. A. Polman: Effect of vitamin $\mathrm{E}$ on membranes of the intestinal cell. Proc. nat. Acad. Sci. (Wash.) 1968, 61, 982-988.

Molenaar, J., J. Vos, F. C. Jager \& F. A. Hommes: The influence of vitamin $\mathrm{E}$ deficiency of biological membranes. An ultrastructural study on the intestinal epithelial cells of ducklings. Nutr. Metabol. 1970, 12, 358-370.

Mouwen, J. M. V. M.: White scours in piglets at three weeks of age. Thesis, Univ. Utrecht 1972, 116 pp.

Nafstad, I. \& S. Tollersrud: The vitamin E-deficiency syndrome in pigs. I. Pathological changes. Acta vet. scand. 1970, 11, 452480.

Porta, E. A., F. A. de la Iglesia \& W. S. Hartroft: Studies on dietary hepatic necrosis. Lab. Invest. 1968, 18, 283-297.

Schofield, G. C. \& A. M. Atkins: Secretory immunoglobulin in columnar epithelial cells of the large intestine. J. Anat. (Lond.) 1970, 107, 491-504.

Sibalin, M. \& N. Bjørkman: On the fine structure and absorptive function of the porcine jejunal villi during the early suckling period. Exp. Cell Res. 1966, 44, 165-174.

Taylor, D. J.\&W.F. Blakemore: Spirochaetal invasion of the colonic epithelium in swine dysentery. Res. Vet. Sci. 1971, 12, 177-179.

Teige, J. jr., K. Nordstoga \& J. Aursjø: Influence of diet on experimental swine dysentery. 1. Effects of a vitamin $\mathrm{E}$ and selenium deficient diet supplemented with $6.8 \%$ cod liver oil. Acta vet. scand. 1977, 18, 384-396.

Teige, J. jr., F. Saxegaard \& A. Frøslie: Influence of diet on experimental swine dysentery. 2. Effects of a vitamin $\mathrm{E}$ and selenium deficient diet supplemented with $3 \%$ cod liver oil, vitamin E or selenium. Acta vet. scand. 1978, 19, 133-146.

Thake, D. C.: Jejunal epithelium in transmissible gastroenteritis of swine. An electron microscopic and histochemical study. Amer. J. Path. 1968, 53, 149-168. 
Vos, J.: Cellulaire membranen bij vitamine E gebrek. Een ultrastruktureel en biochemisch onderzoek van de lever bij de Pekingeend. (Cellular membranes in vitamin $\mathrm{E}$ deficiency. An ultrastructural and biochemical study on the liver of the Pekingduckling). Thesis, Univ. Groningen 1972, $96 \mathrm{pp}$.

\section{SAMMENDRAG}

Ultrastrukturelle forandringer $i$ kolonepitelceller ved vitamin $E$ og selenmangel hos gris.

Mangelgrisene viste nedsatt kontrast i de intracellulære membraner i epitelcellene i kolon sammenlignet med griser gitt tilskudd av vitamin E og selen. Av andre forandringer som ofte opptrådte hos mangeldyra var et redusert antall microvilli med et kort og uregelmessig utseende, oppsvulmede mitokondrier og ødem mellom cellene. Disse morfologiske forandringer er tilskrevet den mangelfulle tilf $\varnothing r s e l$ av vitamin $\mathrm{E}$ og selen, selvom man ikke utelukker at intestinale faktorer kanskje kan ha deltatt i utviklingen av lesjonene. Det er videre fremhevet at griser fra ett av eksperimentene hadde tydeligere membraner enn de andre dyra som ble unders $\varnothing \mathrm{kt}$.

(Received May 11, 1978).

Reprints may be requested from: Jon Teige jr., The National Veterinary Institute, P. O. Box 8156, Oslo Dep., Oslo 1, Norway. 